\title{
ANTONIO J. GIL GONZÁLEZ, + NARRATIVA(S): INTERMEDIACIONES NOVELA, CINE, CÓMIC Y VIDEOJUEGO EN EL ÁMBITO HISPÁNICO. EDICIONES UNIVERSIDAD DE SALAMANCA, SALAMANCA 2012. PÁGS. 364.
}

\begin{abstract}
Raúl Fernández Jódar, reseña de Antonio J. Gil González: + Narrativa(s): Intermediaciones novela, cine, cómic y videojuego en el ámbito hispánico [review of Antonio J. Gil González: + Narrativa(s): Intermediaciones novela, cine, cómic y videojuego en el ámbito hispánico], Studia Romanica Posnaniensia, Adam Mickiewicz University Press, Poznań, vol. XL/2: 2013, pp. 150-151. ISBN 978-83-232-2597-3. ISSN 0137-2475. eISSN 2084-4158.
\end{abstract}

Uno de los grandes puntos débiles de la filología y de los estudios literarios en concreto siempre ha sido el andar muy a remolque de los tiempos, sumida en conceptos arcaicos y con un sentido del canon casi inamovible. Y más si cabe en el ámbito hispánico.

Esto sobre todo se ha reflejado en el objeto de estudio en sí mismo. Los textos estudiados, por el mero hecho de serlo, se convierten en prestigiados y viceversa, los textos prestigiados son los que se estudian. Este círculo se limita por otra parte a la forma en la que se presentan los textos. El libro como objeto siempre se ha considerado un elemento fundamental para el estudio de la narrativa y no se entiende sin su presencia.

Justamente por todo lo afirmado hasta ahora, la publicación a finales de 2012 del libro de Antonio J. Gil González titulado + Narrativa(s): Intermediaciones novela, cine, cómic y videojuego en el ámbito hispánico supone un valiente y fresco cambio de perspectiva digno de respeto, ya que, como el mismo título indica, la obra se centra en el estudio de las intermediaciones que surgen entre diferentes formas de expresión artística narrativa. Es decir, es un intento de esquematización de las diferentes formas en las que se pueden interrelacionar medios artísticos narrativos prestigiados como la novela y otros medios narrativos en proceso de prestigización como el cine, el cómic o el videojuego, todo ello partiendo de tres disciplinas como la literatura comparada, la semiótica de la cultura y los estudios culturales.

Para hacerlo todavía más relevante si cabe, el estudio intenta destacar los elementos hispánicos de las intermediaciones narrativas, ya sea tomando como base de análisis obras de dicho ámbito o comparándolas con otras pertenecientes al mainstrean. De esta forma, el autor pretende demostrar las similitudes entre ambos ámbitos.

Curiosamente, el título de cada capítulo hace referencia a un tiempo o modo gramatical. No es esta una metáfora baladí sino que hace referencia a la gramática entendida como la más antigua tradición escolar en la que se trata de abordar el estudio global de la cultura. Así, el primer capítulo, capital en el conjunto de la obra, se titula "Presente continuo. Declinaciones de la intermedialidad" y en él justamente se destaca la necesidad de un nuevo enfoque filológico sobre todo lo relativo a la nueva cultura audiovisual y sus repertorios intermediales, además de lo necesario de asegurar cierta unidad y legibilidad para su estudio futuro. En este sentido, son reveladores los dos cuadros con los que concluye el capítulo y en los que se presentan por una parte los ejes intramedial e intermedial y por otra se ejemplifican las diferentes subespecies derivadas de la ilustración, la reescritura y la transficción.

La redacción del conjunto de la obra está planteada como si de una moderna rayuela teórica se tratara y cada capítulo puede ser leído como una unidad aislada autoconcluyente. Por eso, tras la lectura del primer capítulo, la lectura del cuarto titulado "Pluscuamperfecto. Los ciclos adaptativos y la Ecdótica Freak. El caso del espía desmemoriado" podría ser una estupenda continuación ya que en dicho capítulo se analiza en conjunto un ciclo adaptativo completo, en concreto el que afecta 
a todas las intermediaciones de las series de Bourne y XIII. Dicho análisis no deja cabo suelto en las intermediaciones que plantean dichos mundos narrativos, de lo que da buena cuenta el cuadro final del capítulo.

Como afirmábamos antes, a lo largo de la obra el ámbito hispano aparece tratado ya sea como elemento directo a través de diferentes ejemplos narrativos, ya sea como elemento alegórico en narrativas anglosajonas. En este sentido es sintomático el título del tercer capítulo: "Imperativo: Los ciclos (inter)genéricos. El poder de las imágenes y algunas imágenes (locales) del poder global”. En él se ejemplifica la visión de lo local a través del poder global, es decir, y sirva como modelo, de lo hispano a través de lo anglosajón en la narrativa, y de qué forma se construye la imagen del mundo según la localización del poder.

Fundamental también se podría considerar el capítulo quinto "Pretérito imperfecto (desde la novela). La masificación del canon: de Don Quijote a Donkey Xote” en el que se plantea el camino seguido desde la consideración de una obra parte del canon hasta formar parte de la cultura de masas. En este caso se centra en la universal figura del Quijote. Cabe añadir que en el octavo y último capítulo "Futuro imperfecto (desde el videojuego —y los nuevos medios-). La constitución del primer campo cultural del siglo XXI" se plantean pinceladas que esperemos que el autor desarrolle en futuras obras en las que se puede intuir el análisis recorrido no desde el canon hasta la cultura de masas sino de la cultura a la contracultura y cómo esta se convierte en canon.

Para finalizar, no podemos dejar de señalar que el autor y la editorial no han perdido la oportunidad de convertir la obra en un ejemplo en sí mismo de intermedialidad. Por una parte, el libro está ricamente ilustrado con ejemplos de las narrativas investigadas para que aquellos que no estén familiarizados con ellas no dejen de percibir el detalle de lo analizado. Por otra parte, el libro tiene una versión digital enriquecida disponible en un sitio al cual se puede acceder mediante la clave que aparece en el libro y en el punto de lectura que lo acompaña. Incluso, dispone de un código QR para facilitar el acceso a la información del sitio, el cual se irá ampliando de manera trimestral ya desde este año 2013.

En conclusion, la obra presenta una visión amplia, integradora y sobre todo, imprescindible, de las relaciones intermediales que se establecen entre las diferentes formas narrativas. Además, plantea una metodología de análisis sólida como base para futuras investigaciones. Por todo ello, estamos seguros de que nos encontramos ante una investigación que ayudará en gran medida al asentamiento de las nuevas visiones de la narrativa multimedia en la cultura.

Raúl Fernández Jódar Universidad Adam Mickiewicz de Poznań

\author{
MAGDA POTOK, EL MALESTAR. LA NARRATIVA DE MUJERES \\ EN LA ESPAÑA CONTEMPORÁNEA. WYDAWNICTWO NAUKOWE UAM, \\ POZNAŃ 2010. PÁGS. 433.
}

\begin{abstract}
Marta Segarra, reseña de Magda Potok: El malestar. La narrativa de mujeres en la españa contemporánea [review of Magda Potok: El malestar. La narrativa de mujeres en la españa contemporánea], Studia Romanica Posnaniensia, Adam Mickiewicz University Press, Poznań, vol. XL/2: 2013, pp. 151-153. ISBN 978-83-232-2597-3. ISSN 0137-2475. eISSN 2084-4158.
\end{abstract}

